WITH most of Dr. Dietz's comments on my note I am in agreement. In particular, I find his answer to my second objection, namely, the formation of sial by scraping and squeezing out of undifferentiated 'sial-sima' through the sliding under of the oceanic basement most illuminating.

However, I must still take issue with him on the nature of the upper mantle as witnessed by the existence of deep-focus earthquakes. These cannot, in my opinion, represent merely temporary accumulations of stress in a long-term easy creep material. The location of the conical $45^{\circ}$ failure zones must be at least as old as the system of deep sea trenches, island arcs and continental mountain systems they underlie. True, they appear to shift discontinuously by distances of the order of $200 \mathrm{~km}$. as each phase of the orogenic cycle comes into play. However, as Van Bemmelen has demonstrated, the sequence of four parallel thrust planes in the Indonesian arc system goes back at least as far as the base of the Secondary, a period of two hundred millions of years. The most natural explanation of this phenomenon may be similar to that of the development of Luders lines in plastically deformed metals, with old zones of failure hardening up and passing the critical stress on periodically to undistorted material. It seems to me, in any event, somewhat perverse to attribute events occurring $800 \mathrm{~km}$. down in the mantle to causes located in the first $50 \mathrm{~km}$. from the surface; the reverse seems much more likely. If this is so the downward moving convection current under the continental margins might be pictured not as a flow of liquid against a gravitational field through a rigid and highly compressed rock layer, but rather as a displacement downwards of successive blocks of the upper mantle into the presumably secularly softer material of the lower mantle (Fig. 1). Asthenosphere material could thus be imagined as separating into an upper hardened sialic layer under the continental edge and a lower

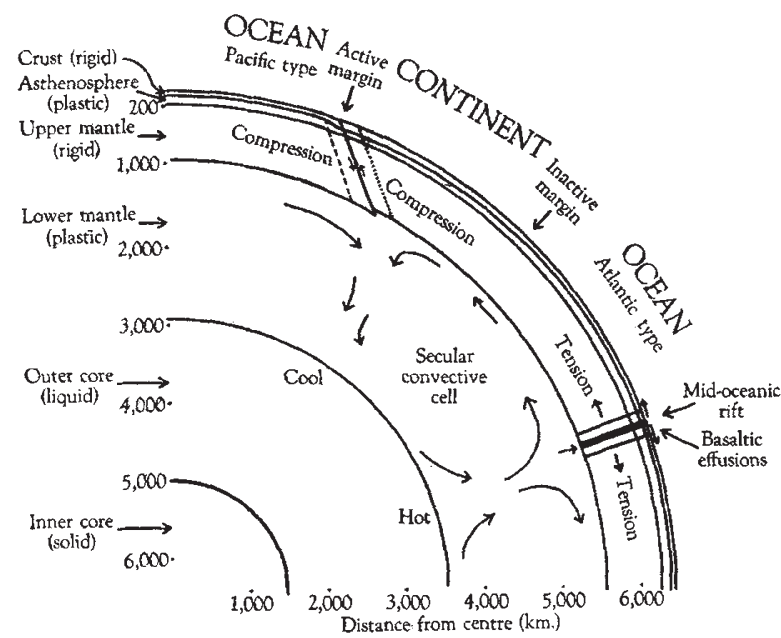

Fig. 1. Schematic Earth section showing one secular convection cell in plastic lower mantle and its reactions on the more rigid upper mantle and through the asthenosphere to the crust. On the right is shown, corresponding to rising mantle current, a midoceanic rift through which magrma derived from the lower mantle, directly or indirectly, exudes to the surface through successively opened and consolidated tension cracks. On the left is shown, corresponding to a sinking mantle current, an advancing continental edge with trench and mountain building system with the oceanic side of the upper mantle block thrust down into the lower mantle. Between is the inactive continental edge marked only by an increased thickness of the crust and the corresponding

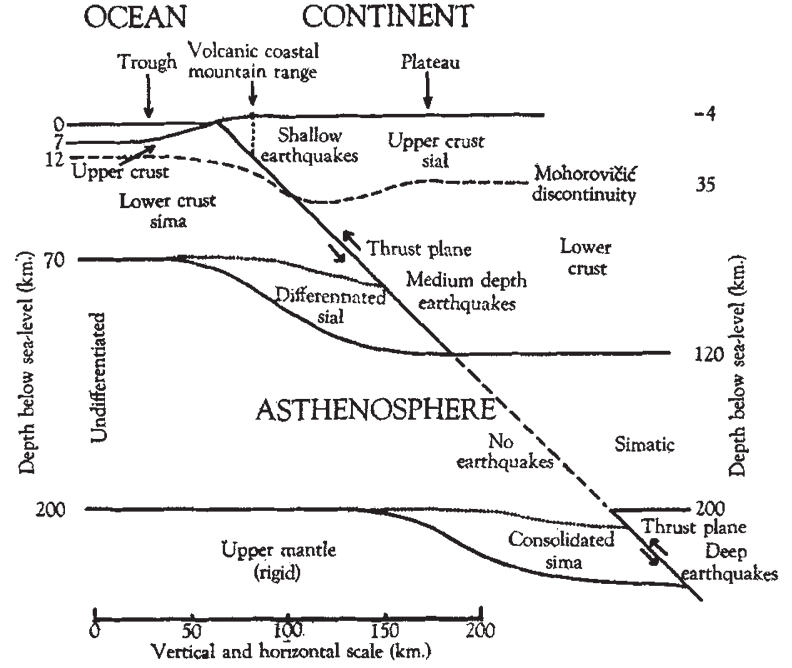

Fig. 2. Section of an idealized continental thrust plane system illustrating Dietz's hypothesis of continental sialic differentiation. The upper block of asthenospheric sial will in the actual case not be so clearly demarcated from the basal crust as is shown, nor will the corresponding block of sima with the sinking upper mantle. The former, as it is differentiated, tends to rise vertically to jam with, and push up, granite batholiths. The vulcanicity associated with the mountain building is assumed to arise from the activity of the thrust plane itself

hardened simatic layer filling in and overlying the depressed former upper mantle surface (Fig. 2).

These remain very tentative suggestions but may serve to pull together in one coherent whole the evidence derived from recent geophysical and oceanographic studies.

J. D. BERNAL

Is two recent papers P. S. Dietz ${ }^{1}$ and H. H. Hess ${ }^{2}$ have made similar proposals in which, guided by now discoveries made about palæomagnetism and the ocean floors, they have combined features of several older theories into one which appears to fit many observations. J. D. Bernal has welcomed these views (first communication) and commented on particular points and I should like to do the same.

Essentially, Dietz and Hess agree that major convection currents flow in the mantle, as long advocated by Arthur Holmes, F. A. Vening Meinesz ${ }^{3}$ and many others.

These currents are held to rise under the active mid-ocean ridges and sink under the belts of active mountains and island arcs which lie along some continental margins. The locations of these are well known and so it is possible to sketch on a globe the approximate directions of motion of the upper surfaces of these currents flowing from the mid-ocean ridges towards the active continental mountain systems.

\section{Mid-Ocean Ridges}

A current rising under the mid-Atlantic ridge provides an explanation for the earlier views of $\AA$. Wegener ${ }^{4}$ and A. L. Du Toit ${ }^{5}$ that the opposite coasts of the ocean have moved apart. The presence of this current can also explain the central position of the ridge.

The westward current bears the Americas towards and over the limb where the current is supposed to descend beneath the Cordillera and the Andes, 